\title{
ANALISIS STRATEGI KEUANGAN MATRIKS UNTUK MENGETAHUI TINGKAT PERTUMBUHAN VALUE CREATION PERUSAHAAN BERKELANJUTAN
}

\author{
Kiagus Ridwan \\ Fakultas Ekonomi Universitas Negeri Jakarta \\ Email: illutinati@gmail.com \\ Unggul Purwohedi \\ Fakultas Ekonomi Universitas Negeri Jakarta \\ Email: unggul_purwohedi@yahoo.com \\ Ari Warokka \\ Fakultas Ekonomi Universitas Negeri Jakarta \\ Email: ari.warokka@gmail.com
}

\begin{abstract}
ABSTRAK
Perkembangan industri panas bumi di kawasan ASEAN belum optimal, sehingga perusahaan perlu menganalisis kemampuan keuangannya untuk mengetahui permasalahan yang terjadi di dalam perusahaan. Konsep penciptaan nilai dan manajemen pertumbuhan dapat digabungkan untuk menjadi sebuah strategi keuangan matriks. Strategi ini merupakan alat diagnostik yang dapat digunakan untuk mengevaluasi dan menavigasi melalui perubahan kondisi keuangan dan menggambarkan situasi penciptaan nilai seta manajemen pertumbuhan pada periode tertentu, berdasarkan peringkat dan menempatkannya pada matriks kuadran. Penelitian ini menganalisis variabel Growth in sales, SGR, ROIC, WACC, dan spread EVA. Dalam strategi ini, setelah diketahui kondisi keuangan, maka perusahaan dipetakan ke dalam 4 grafik kuadran. Hasilnya bahwa pada tahun penelitian, hampir semua perusahaan yang bergerak di bidang energi panas bumi di kawasan ASEAN berada dalam kondisi defisit kas. Hal ini menyiratkan bahwa perusahaan perlu meningkatkan dana dari sumber internal maupun eksternal dan mempertahankan kemampuan laba. Di masa mendatang, kondisi keuangan perusahaan diharapkan masuk ke kuadran I dan II.
\end{abstract}

Kata kunci: Pertumbuhan penjualan, Tingkat Pertumbuhan Berkelanjutan, penyebaran EVA, Penciptaan Nilai 


\section{PENDAHULUAN}

Di kawasan ASEAN baru ada 2 negara yang sudah mengeksploitasi dan memanfaatkan energi geothermal untuk listrik, yaitu Indonesia dan Filipina, sedangkan di negara Malaysia baru tahap survei pendahuluan saja (belum ada kegiatan eksploitasi). Investasi geothermal sangat tergantung kondisi lapangan, resiko mitigasi, dan kemampuan keuangan perusahaan, hal ini dipertimbangkan dengan cermat sebelum melakukan investasi pada proyek geothermal (Wintolo et al. 1994:2). Saat ini perkembangan industri geothermal di kawasan ASEAN masih belum optimal, padahal pemerintah setempat telah mendukung untuk percepatan pembangunan proyek geothermal, termasuk berbagai pemberian insentif pajak, keuangan, dan pembiayaan. Menurut Ibrahim (2011), perusahaan industri geothermal saat ini banyak juga yang mengalami masalah keuangan, sehingga banyak perusahaan yang menunda kegiatan eksploitasinya. Hal ini sependapat dengan Santosa (dalam economic challenges group discussion,2014). Kondisi seperti ini juga hampir sama halnya dengan negara Filipina, sebagai negara berkembang juga, yang sama berada di kawasan ASEAN. Menyikapi masalah tersebut di atas, sebelum menetapkan keputusan rencana investasi, terlebih dahulu hendaknya perusahaan lebih cermat memahami kondisi value creation perusahaan itu sendiri, serta sepatutnya perusahaan memiliki dana surplus untuk kegiatan proyek selanjutnya.

Pada penelitian sebelumnya terkait strategi keuangan matrik, menunjukan pola keuangan matriks ini dapat digunakan untuk mengetahui kondisi value creation suatu perusahaan yang dapat menjadi salah satu pertimbangan dalam proses pengambilan keputusan keuangan. Menuerut Devie (2003:10), untuk menganalisa pertumbuhan (value creation) perusahaan dapat mengunakan strategi keuangan matriks, yang merupakan konsep strategi yang dapat menyelaraskan antara pertumbuhan perusahaan (economic growth) dengan efektivitas keputusan pembiayaan dan investasi.

Secara praktis dimungkinkan pula konsep strategi keuangan matriks ini digunakan pada cluster industry, untuk menilai tingkat rata-rata value creation dalam jangka periode waktu tertentu, dengan mengunakan populasi yang lebih banyak, kriteria lebih 
sampel yang lebih spesifik, dan periode waktu yang lebih lama agar dapat mengukur rata-rata pertumbuhan (de Wet and Jager, 2006).

\section{Rumusan Masalah}

1. Bagaimana kondisi keuangan perusahaan dan tingkat value creation?

2. Bagaimana posisi perusahaan dari kondisi pertumbuhan perusahaan dan tingkat value creation di dalam 4 bagian kuadran matriks?

3. Apa strategi keuangan yang dapat dilakukan oleh perusahaan setelah mengetahui kondisi value creation pada kuadran matriksnya?

\section{Tujuan Penelitian}

1. Untuk mengetahui kondisi keuangan perusahaan dan tingkat value creation.

2. Untuk mengetahui posisi perusahaan dari kondisi pertumbuhan perusahaan dan tingkat value creation di dalam 4 bagian kuadran matriks.

3. Untuk mengetahui strategi keuangan yang dapat dilakukan oleh perusahaan setelah mengetahui kondisi value creation pada kuadran matriksnya.

\section{TELAAH PUSTAKA}

\section{Konsepsi strategi keuangan matriks}

Didasarkan pada pendapat Devie (adapted from Hawawini \& Viallet, 1998:507) memperkenalkan konsep strategi keuangan matriks ini, dengan mempresentasikan sebuah diagnostic tool yang dapat digunakan untuk evaluate and navigate melalui financial progress dari sebuah perusahaan. Strategi keuangan matriks menggambarkan situasi value creation dan growth management perusahaan atau industri pada periode tertentu dengan cara memberi peringkat dan menempatkannya pada kuadran tertentu dalam matriks. Value creation pada return spread EVA adalah perbedaan antara rasio return on invested capital (ROIC) dengan rasio weight average cost of capital (WACC) yang digunakan sebagai ukuran untuk value creation spread EVA. Nilai spread EVA ini menjadi acuan untuk menentuakan tingkat corporate growth. Bila nilai positif dari return spread EVA mengindikasikan sebuah value creation, sedangkan nilai negatif dari return spread EVA mengindikasikan sebuah value destruction. Hasil penelitian Abdullah (2003:142), dengan EVA akan mendapatkan hasil perhitungan pertumbuhan 
nilai ekonomis perusahaan yang lebih realistis. DeMello (2006:131), EVA merupakan ukuran kinerja keuangan yang lebih mampu menangkap laba ekonomis perusahaan yang sebenarnya dibandingkan metode-metode lain. Kegiatan yang memberikan nilai sekarang dari total EVA yang positif menunjukkan adanya penciptaan nilai dari proyek tersebut dan dengan demikian sebaiknya di ambil.

Growth dan cash management diukur dengan mengambil perbedaan antara nilai SGR dan nilai pertumbuhan aktual pada penjualan (actual growth in sales). Jika perbandingan berupa nilai positif (SGR > Growth in sales), hal ini mengindikasikan bahwa ada cumulative cash surplus. Namun sebaliknya bila perbandingan berupa nilai negatif (SGR < Growth in sales), bearti di perusahaan tersebut terjadi cumulative cash deficits. Strategi keuangan matriks mengindikasikan value creation (positive or negative) yang terletak pada sumbu vertikal. Alat ukur yang digunakan adalah return spread EVA (the ROIC less the WACC). Value creation terjadi ketika ROIC > WACC, yang di indikasikan pada bagian atas (positif) pada sumbu-Y. Sedangkan Value destruction terjadi bila ROIC < WACC, di indikasikan pada bagian bawah (negatif) dari pada sumbu-Y (Hawawini and Viallete, 2011:550). Sedangkan mengetahui posisi pertumbuhan cash surpluses ataupun cash deficits, yaitu dapat di ketahui pada indikasi sumbuh horizontal pada matrik. Jika perusahaan tumbuh terlalu cepat, yang ditunjukkan oleh nilai growth in sales lebih besar pada SGR, maka perusahaan akan menuju cash deficits, posisi ini dicerminkan pada posisi sebelah kanan pada sumbuh-X. Di posisi lain, sales and assets perusahaan mengalami pertumbuhan yang lebih lambat dari pada SGR, hal ini menunjukkan ada peningkatan cash surpluses, situasi ini diindikasikan oleh sebuah nilai positif di bagian sebelah kiri sumbuh-X (Hawawini and Viallete, 2011:551).

Setelah perusahaan-perusahaan dikelompokkan ke dalam masing-masing kuadran, lalu akan di buat strategi keuangan agar nantinya perusahaan dapat menghasilkan kinerja yang lebih baik dari pada keputusan akan yang diambil (Purnamasari et al, 2013:104). Matriks keuangan membagi perusahaan berdasarkan kinerja yang dicapai, yang tercermin dalam rasio keuangan, kemudian di bagi menjadi 4 bagian kuadran dan akan memberikan usulan strategi keuangan sesuai dengan posisi kuadran perusahaan masing-masing (Hawawini and Viallete, 2011:551). 
Terkait pula dengan analisa pertumbuhan perusahaan (value creation), de Wet dan Hall (2006:15) meneliti model keuangan matriks untuk mengukur Economic Value Added. Hasil penelitiannya menunjukan posisi pertumbuhan value creation masingmasing perusahaan di Johannesburg Securities Exchange South Africa (JSE) tahun 1993-2002. Terdapat lagi penelitian dari Purnamasari et al. (2012:11), menunjukan kondisi keuangan perusahaan PT Myoh Technology Tbk dapat mengalami pertumbuhan nilai economic value added di internal maupun eksternal perusahaan di setiap tahunnya. Penelitian Joni dan Hendrawan (2013:4), hasilnya dapat menentukan strategi keuangan matriks PT Sat Nusapersada Tbk dan PT Citra Tubindo Tbk. Penelitian Yuniawati (2012:64), yang hasilnya menunjukkan dapat memahami value creation growth, yaitu berupa kemampuan BPR di wilayah Jawa Timur untuk tumbuh dan menghasilkan nilai tambah semakin meningkat dari tahun ke tahun. Demikian pula penelitian oleh Wahyudi (2013:102), yang menganalisis strategi keuangan matriks dan optimalisasi struktur modal untuk pertumbuhan perusahaan berkelanjutan (studi pada PT Adhimix Precast Indonesia), hasilnya menunjukan dapat memahami pengendalian posisi value creation growth yang berkelanjutan pada kuadran II.

\section{Growth in sales}

Growth in sales merupakan tingkat pertumbuhan yang ditentukan dengan melihat kemampuan financial, tingkat pertumbuhan ini dapat dibedakan menjadi 2, yaitu pertumbuhan dari kekuatan keuangan yang ada di perusahaan itu (internal growth rate) dan pertumbuhan yang berkesinambungan dari kekuatan sumber pendanaan ekternal (sustainable growth rate). Penelitian Widarjo dan Setiawan (2009:129) bahwa pertumbuhan penjualan (sales growth) mencerminkan kemampuan perusahaan dari waktu ke waktu, semakin tinggi tingkat pertumbuhan penjualan suatu perusahaan maka perusahaan tersebut berhasil menjalankan strateginya. Menurut Saragih et.al (2012:6), corporate growth dalam manajemen keuangan di ukur berdasar perubahan sales, bahkan secara keuangan dapat dihitung berapa pertumbuhan yang seharusnya (sustainable growth rate) dengan melihat keselarasan keputusan investasi dan pembiayaan. Dengan kemajuan $G$ in sales yang terlalu tinggi maka diilustrasikan bahwa akan terjadinya suatu cash deficit pada perusahaan tersebut. Menurut Ross et al. (2012:109) dinyatakan bahwa growth in sales merupakan tingkat pertumbuhan 
maksimum yang dapat di capai oleh corporate tanpa membutuhkan external fund. Dapat diartikan sebagai pertumbuhan yang hanya diperoleh dari retained earning. Actual growth value (nilai pertumbuhan aktual) ini selalu lebih rendah bila dibandingkan dengan nilai SGR, disebabkan nilai actual growth tidak memperkenankan penambahan utang jangka panjang ataupun penerbitan surat utang. Secara matematis tingkat pertumbuhan internal ini dapat di hitung dengan: Growth in sales $=($ net sales after-net sales before) / net sales before.

\section{Sustainable Growth Rate}

Sustainable growth rate (SGR) dari pada perusahaan didefinisikan sebagai nilai maksimum saat sebuah perusahaan dapat tumbuh secara sustainable basic tanpa membutuhkan dana tambahan untuk meningkatkan keuangan jangka panjang, seperti dari sumber dana pinjaman dan obligasi. Amouzesh, et al. (2011:311) konsep sustainable growth rate bernilai karena menekan hubungan antara empat unsur penyusun sustainable growth rate dengan sustainable growth rate itu sendiri. Penelitian Wahyudi (2015:39), bila terjadi pertumbuhan perusahaan berkelanjutan (SGR) barulah dapat menghasilkan tingkat pengembalian yang mampu menutup biaya penggunaan dana, dan diharapkan perusahaan memiliki nilai yang optimal, begitu pula sebaliknya. Menurut Ross et al. (2012:110), sustainable growth rate ialah tingkat maximum growth yang dapat di capai oleh corporate tanpa melakukan pembiayaan modal, tetapi dengan membandingan (while maintaining constant) antara utang dengan modal perusahaan (debt to equity ratio). Menghitung sustainable growth rate (SGR) dapat dengan Return on Equity dengan retention, atau $S G R=(\mathrm{ROE} \times \mathrm{b})$.

\section{Return on Invested Capital}

Mengetahui nilai Return on Invested Capital (ROIC) cukup penting bagi perusahaan, karena profit yang besar belum dapat dijadikan ukuran yang tepat untuk menyatakan efisiensi kinerja suatu perusahaan. ROIC merupakan rasio perbandingan net profit after tax dengan total aktiva. Menurut Koller et.al (2005:61), ROIC menunjukkan tingkat efisiensi penggunaan dan pengalokasian sumber daya perusahaan dan tingkat efektivitas pengaturan dan pengelolaan sumber daya perusahaan. Penelitian Fauziah (2003:35) menyatakan ROIC merupakan salah satu indikator yang dapat digunakan untuk mengukur efektivitas pemanfaatan sumber daya dan kapabilitas 
perusahaan dalam menciptakan nilai yang tercermin dalam kinerja keuangan perusahaan. Sedangkan menurut Jiang et.al. (2007:117) perusahaan yang memiliki ROIC yang tinggi akan mampu meningkatkan pendapatan perusahaan dengan total return kepada para pemegang saham (shareholders). Dengan mengetahui rasio ini, maka akan dapat diketahui pula tingkat efisiensi dari kinerja suatu perusahaan dalam memanfaatkan aktivanya untuk kegiatan operasional. Menurut Hawawini and Viallete (2011:535), cara menghitungnya mengunakan rumus: $\mathrm{ROIC}=($ NOPAT $: I C)$

\section{Weighted Average Cost of Capital}

Weight Average Cost of Capital (WACC) ialah total setiap komponen modal shortterm debt dan long-term debt atau (cost of debt) serta setoran modal saham (cost of equity) yang diberikan bobot sesuai dengan proporsinya, yang berada dalam struktur modal perusahaan. Terkait rasio WACC, menurut Hasnan dan Pudjiastuti (2009:61), WACC merupakan metode yang dipergunakan untuk mengkaitkan keputusan investasi dengan keputusan pendanaan. Sartono (1996:302), struktur modal yang optimal adalah struktur modal yang menciptakan suatu kombinasi sumber dana permanen sehingga mampu memaksimumkan kemakmuran para pemegang saham. Tunggal (dalam Panjaitan, 2005:33) menyebutkan bahwa WACC terdiri dari beberapa komponen, yaitu biaya utang (cost of debt), biaya saham preferen (cost of preferred stock), dan biaya ekuitas biasa (cost of common equity). Menurut Hawawini and Viallete (2011:535) WACC dapat dirumuskan: (After-tax cost of debt $\times$ Percentage of debt capital $(D))+$ (Cost of equity $\times$ Percentage of equity capital(E)). Sedangkan Nugraha (2012:6) mengunakan rumus: $\mathrm{WACC}=(\mathrm{D} \times \mathrm{rd}(1-\operatorname{tax})+(\mathrm{E} \times \mathrm{re}))$.

\section{Economic Value Added}

Brigham dan Houston (2006:68) berpendapat bahwa EVA merupakan suatu estimate dari economic profit yang sebenarnya dari bisnis di tahun tersebut yang berbeda dari pada laba akuntansi. Menurtut Steward et al. (1998) dalam Rani (2012:25), EVA di anggap merupakan satu-satunya pengukuran kinerja keuangan yang komplek yang mempertimbangkan beban dana dalam rangka penciptaan nilai (value creation) perusahaan. Penelitian de Jager (2007:28) menyatakan EVA dapat digunakan untuk menentukan seberapa besar nilai tambah yang diperoleh dari hasil aktifitas 
operasi perusahaan tersebut. Namun Erasmus and Lambrechts (2006:21) mencatat kelemahan EVA adalah sulitnya perbandingan antara perusahaan dan unit bisnis dengan ukuran yang berbeda. Konsep EVA dilandasi oleh pemikiran bahwa corporate akan benar-benar menguntungkan dan dapat menciptakan nilai bila profit lebih tinggi dari pada biaya modal yang dipakai untuk kegiatan operasi. Berdasarkan Hawawini and Viallete (2011:545), penghitungan nilai EVA dapat mengunakan rumus: $\mathrm{EVA}=(\mathrm{ROIC}$ - WACC) $\times$ Invested capital atau ((NOPAT / IC) - WACC) x IC. Sedangkan dalam Hawawini and Viallete (2010:536), nilai akhir yang akan digunakan pada kuadran mariks adalah rumus spread EVA, yang dapat diformulasinya yaitu: spread EVA= $(R O I C-W A C C)$.

Jika EVA > nol, artinya telah terjadi penambahan nilai ekonomis ke dalam perusahaan dari bisnis itu. Namun jika EVA = nol, artinya secara ekonomis kondisi keuangan perusahaan mengalami impas, disebabkan semua profit digunakan untuk membayar kewajiban kepada penyandang dana, baik kreditur maupun pemegang saham. Jika EVA < nol, artinya tidak ada nilai tambah ke dalam perusahaan tersebut, disebabkan profit yang tersedia perusahaan tersebut tidak bisa memenuhi keinginan para pemegang saham (shareholders).

\section{Kerangka Pemikiran}

Kegiatan ini melakukan analisa tingkat value creation dan kondisi financial position, dan menentukan posisi tingkat rata-rata pertumbuhan keuangan perusahaan dalam 4 pola kuadran matriks, serta strategi keuangan yang dapat dilakukan oleh masing-masing perusahaan setelah mengetahui kondisi value creation pada kuadran matriksnya. Apabila nilai EVA suatu corporate menaik, menginisialkan bahwa kondisi corporate performance tersebut dalam keadaan semakin bagus, dan dalam posisi financial sehat. Begitu pula sebaliknya bila nilai EVA suatu corporate cenderung merendah, maka dapat di prediksi bahwa corporate performance tersebut dalam keadaan kurang sehat, dan dalam kondisi mengalami financial risk. Hasil dari analisis variabel tersebut akan dikelompokkan dan diposisikan berdasarkan growth performance yang telah menjadi 4 bagian atau kuadran, yaitu: a) Kuadran IV; korporasi dalam situasi cash deficit dan EVA negatif. b) Kuadran III; korporasi dalam situasi cash surplus dan EVA negatif. c) Kuadran II; korporasi dalam situasi cash surplus dan 
EVA positif. d) Kuadran I; korporasi dalam situasi cash deficit dan EVA positif. Setelah korporasi dikelompokkan ke dalam masing-masing kuadran, selanjutnya akan dikembangkan strategi agar corporate dapat menghasilkan suatu performance yang lebih layak sesuai harapan.

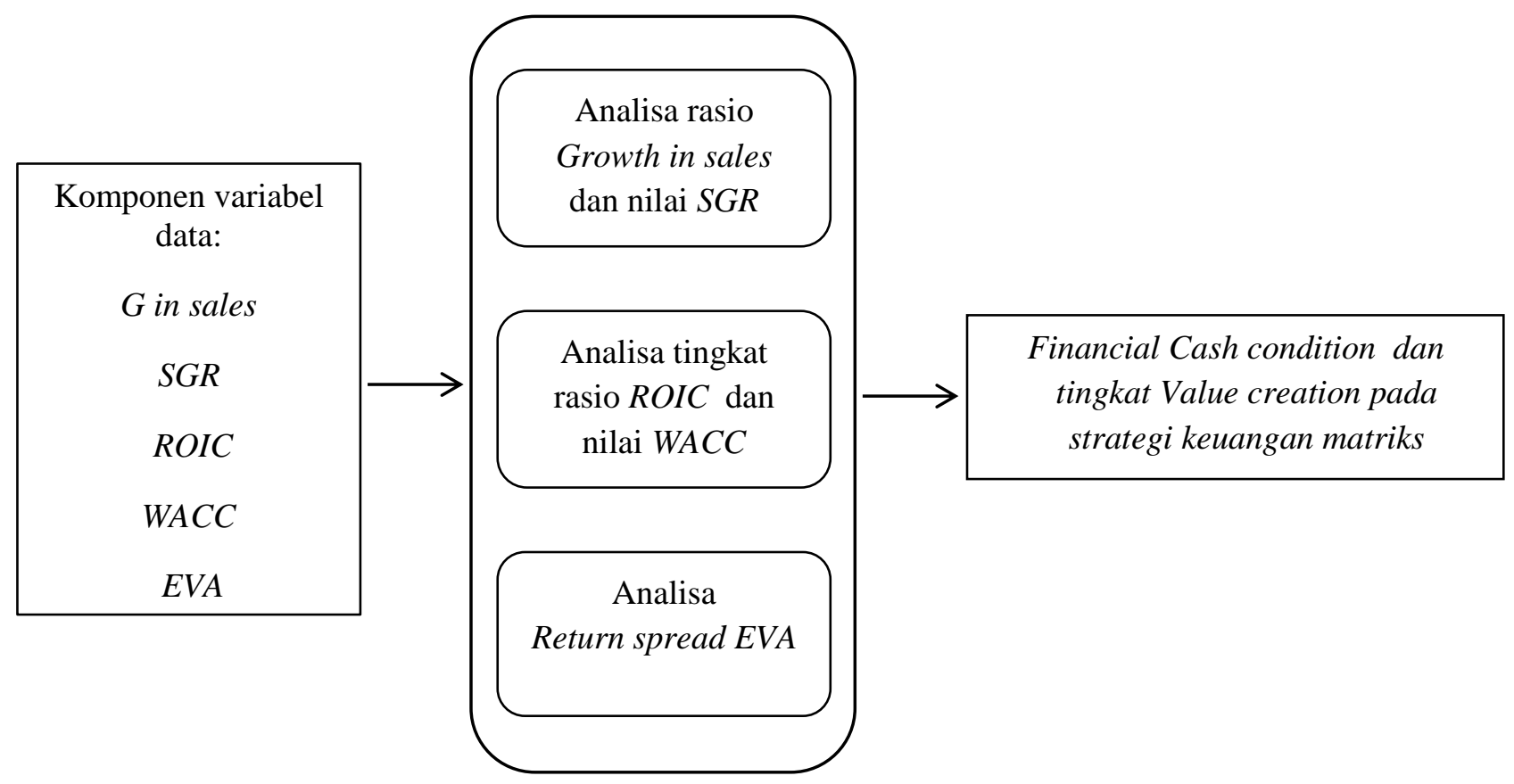

Sumber: diilustrasikan oleh peneliti

\section{Gambar 1. Kerangka pemikiran}

\section{METODE PENELITIAN}

\section{Pendekatan Penelitian}

Desain penelitian ini mengunakan metode desktiptif kualitatif, dengan menggunakan pendekatan studi kasus, yaitu dengan cara mempelajari suatu masalah dalam kondisi tertentu, pengambilan data yang memiliki kriteria, serta dengan menyertakan sumber informasinya. Menurut Strauss dan Corbin dalam Crasswell.J, (dalam Rahmat, P.S., 2009:2), yang dimaksud penelitian deskriptif kualitatif adalah jenis penelitian yang menghasilkan penemuan-penemuan yang tidak diperoleh dengan mengunakan prosedur-prosedur statistik. Bogdan dan Biklan, S. (1992:21-22) menjelaskan bahwa penelitian kualitatif adalah salah satu penelitian yang menghasilkan data deskriptif dapat berupa ucapan atau tulisan, data dan analisa kasus. 
Dasar teori dalam pendekatan kualitatif adalah peneliti berusaha memahami suatu kondisi dan kaitannya dengan menganalisa dokumen tertentu. Objek penelitian adalah tingkat pertumbuhan perusahaan berdasarkan analisis value creation dari spread EVA ke dalam strategi keuangan matriks. Sedangkan subjek penelitian ini adalah perusahaan geothermal yang memiliki konsesi eksploitasi geothermal di kawasan ASEAN khususnya Indonesia dan Filipina. Pendekatan model meliputi analisis variabel-variabel yang akan digunakan dalam financial ratio yaitu variabel Growth in sales, Sustainable Growth Rate (SGR), Return on Invested Capital (ROIC), Weight Average Cost of Capital (WACC), dan Economic Value Added (EVA). Pengumpulan data utama berupa data sekunder. yaitu data financial report yang telah di audit oleh akuntan publik sejak tahun 2010-2014 sebagai bahan analisis. Untuk menambah wawasan dan informasi tambahan maka peneliti juga mengikuti fokus diskusi terkait masalah yang di teliti.

\section{Analisis}

Analisis data merupakan suatu proses mencari dan menyusun secara sistematis data yang diperoleh dari hasil wawancara, diskusi dari kelompok dalam acara diklat, catatatan lapangan, dan dokumen laporan keuangan. Tahapan analisis yang akan dilakukan secara berurutan yaitu mengetahui nilai tingkat growth in sales (pertumbuhan aktual). Lalu menentukan tingkat sustainable growth rate (pertumbuhan seharusnya), kemudian membandingkan growth in sales dengan tingkat pertumbuhan sustainable growth rate. Bila pertumbuhan aktual melebihi pertumbuhan SGR maka diindikasikan mengalami financing problem yaitu cash deficit, karena dana yang disediakan hanya mampu mendukung pertumbuhan SGR. Sebaliknya, apabila pertumbuhan SGR melebihi pertumbuhan aktual maka perusahaan akan mengalami problem pembiayaan yaitu cash surplus. Setelah mengetahui hasil growth in sales dan SGR, maka selanjutnya dilakukan perhitungan Return of Interest Capital (ROIC). Kemudian bila sudah ditehaui nilai ROIC maka akan dikalkulasikan variabel WACC. Selanjutnya akan di analisa untuk nilai EVA. Selanjutnya mengetahui besarnya nilai value creation dalam kondisi pertumbuhan Economic Value Added (EVA) untuk mengukur sampai sejauh mana laba operasi mampu menutup biaya penggunaan dana yang digunakan dalam berinvestasi. Setelah itu barulah menentukan posisi perusahaan dalam grafik 4 kuadran, sekaligus membuat strategi keuangan untuk memperbaiki posisi atau mengembangkan value creation perusahaan tersebut. 
Pengumpulan data dari perusahaan pemegang konsesi geothermal yang ada di kawasan ASEAN, yang menyajian laporan keuangan dalam kurun rentang waktu yang berbeda, yaitu tahun 2010-2014 pada perusahaan yang menjadi subjek penelitian yang sudah di audit oleh akuntan publik. Upaya untuk meningkatkan kredibilitas lainnya yaitu dengan cara meningkatkan ketekunan dan wawasan, hal ini dilakukan dengan cara membaca berbagai sumber referensi terkait permasalahan yang diteliti seperti penelitian terdahulu dan jurnal.

Populasi dan sampel diambil secara purposive sampling dan dibuatkan kriterianya. Dalam melaksanakan penelitian ini, yang menjadi objek penelitian ialah jenis data financial report 2010-2014. Untuk lebih akurat dan sesuai dengan kondisi di lapangan maka dilakukan kajian lanjut mengenai ketentuan beberapa kriteria agar nantinya dapat dijadikan sampel dari populasi yang ada. Sampel yanp diperoleh digunakan apabila memenuhi kriteria. Data sekunder yang dikumpulkan adalah data financial report, dengan kriteria sebagai berikut: 1) Perusahaan yang mempunyai data laporan tahunan keuangan dari tahun 2010-2014 yang telah di audit oleh akuntan publik dan dipublikasikan secara online. 2) Perusahaan yang ikut berinvestasi ataupun joint venture terkait proyek eksploitasi dan produksi geothermal yang sudah memiliki Wilayah Konsesi Pengusahaan Geothermal dari tahun 2010-2014 yang ada di kawasan ASEAN secara clear and clearance, yaitu di Indonesia dan Filipina. 3) Perusahaan yang memiliki aset yang bila di konversi ke nilai rupiah, maka nilai asetnya $>5$ triliun rupiah pada laporan keuangan tahun paling akhir.

Tabel 1.

Daftar komponen formulasi untuk pengukuran variabel

\begin{tabular}{cll}
\hline No. & \multicolumn{1}{c}{ Komponen (\%) } & \multicolumn{1}{c}{ Formulasi Yang Digunakan } \\
\hline 1. & Growth in sales & $\begin{array}{l}\text { G in sales }=\text { (net sales after-net sales } \\
\text { before }) / \text { net sales before }\end{array}$ \\
& & SGR $=\mathrm{b}$ x ROE \\
2. & Sustainable Growth Rate & ROIC $=$ NOPAT / Total Asset \\
3. & Return on Invested Capital & WACC $=(\mathrm{D}$ x rd (1-tax $)+($ E x re $)$ \\
4. & Weight Average Cost of Capital & Spread EVA = ROIC - WAC \\
5. & Spread Economic Value Added &
\end{tabular}

\section{HASIL PENELITIAN DAN PEMBAHASAN}

\section{Deskripsi unit analisis}


Beberapa variabel yang siap di analisa dari laporan keuangan adalah besarnya pertumbuhan nilai Growth in sales ( $G$ in sales), Sustainable Growth Rate (SGR), Return on Invested Capital (ROIC), Weighted Average Cost of Capital (WACC), dan Economic Value Added (EVA). Setelah nilai masing-masing variabel sudah diketahui maka akan diformulasikan ke 2 tabulasi yang berbeda yaitu tabulasi dari nilai pertumbuhan growth in sales dan SGR corporate dan tabulasi dari nilai ROIC, WACC, dan EVA corporate. Kemudian dilakukan pembuatan pola strategi keuangan matriks, melalui tahapan: 1) Membandingkan growth in sales dengan SGR. 2) Mengetahui tingkat value creation atau value destruction. 3) Mengelompokan corporate berlandaskan analisis financial ratio ke dalam pola 4 kuadran. 4) Merekomendasikan kebijakan financial strategy sesuai dengan kuadran pada posisi corporate, yang telah dikelompok dalam suatu peta konteks keputusan investasi dan keputusan pembiayaan ( Hawawini and Viallet 2011:550).

\section{Hasil penelitian dan pembahasan}

Untuk mengetahui kondisi keuangan perusahaan dengan menganalisa tingkat value creation, yang dilakukan dengan cara menganalisis kinerja keuangan yakni tingkat pertumbuhan rata-rata Growth in sales, SGR, spread EVA. Hasil analisa deskriptif kondisi keuangan dan tingkat value creation dapat di lihat pada Tabel 4.1. Selanjutnya dilakukan mapping setelah mengetahui nilai spread EVA dan cash surplus ataupun cash defisit, kemudian ditempatkan dalam 4 bagian kuadran sesuai dengan ketentuan strategi keuangan matriks.

\section{Mengetahui kondisi keuangan perusahaan dan tingkat value creation perusahaan}

Untuk mengetahui kondisi keuangan perusahaan dengan menganalisa kondisi presentase tingkat financial condition dan value creation, dapat dilihat pada Tabel 4.1 dibawah ini:

Tabel 2.

Kondisi keuangan perusahaan dan tingkat value creation setiap perusahaan tahun 2010-2014.

\begin{tabular}{llccccccc}
\hline No. & Company & $\begin{array}{c}\text { G in } \\
\text { sales }\end{array}$ & SGR & $\begin{array}{c}\text { Cash } \\
\text { condition }\end{array}$ & $\begin{array}{c}\text { ROIC } \\
\%\end{array}$ & $\begin{array}{c}\text { WACC } \\
\%\end{array}$ & $\begin{array}{c}\text { spread } \\
\text { EVA }\end{array}$ & $\begin{array}{c}\text { Quadrant } \\
\text { position }\end{array}$ \\
\hline 1. & PT Pertamina & $-0,26$ & 0,88 & $-0,26$ & 0,80 & 1,16 & $-0,35$ & III \\
2. & PT PLN & 2,39 & 0,40 & $-1,99$ & 0,93 & 0,91 & 0,02 & I
\end{tabular}


Jurnal Riset Manajemen Sains Indonesia (JRMSI) | Vol 9, No. 2, 2018

e-ISSN: 2301-8313

http://doi.org/10.21009/JRMSI

\begin{tabular}{|c|c|c|c|c|c|c|c|}
\hline 3. & $\begin{array}{l}\text { PT Indonesia } \\
\text { Power }\end{array}$ & 26,43 & 0,82 & $-25,61$ & 1,06 & 1,33 & $-0,27$ \\
\hline 4 & $\begin{array}{l}\text { PT Sarana Multi } \\
\text { Infrastruktur }\end{array}$ & 3,38 & 0,8 & $-3,31$ & $-6,94$ & 1,13 & $-8,07$ \\
\hline 5. & $\begin{array}{l}\text { PT Rekayasa } \\
\text { Industri }\end{array}$ & 287,87 & 0,46 & $-287,40$ & $-23,23$ & 1,67 & $-24,90$ \\
\hline 6. & PT Wijaya Karya & 10,37 & 0,26 & $-10,11$ & 0,46 & 1,40 & $-0,94$ \\
\hline 7. & $\begin{array}{l}\text { PT Medco Energi } \\
\text { Internasional }\end{array}$ & 3,44 & 2,07 & $-1,36$ & 0,81 & 6,06 & $-5,25$ \\
\hline 8. & $\begin{array}{l}\text { PT Saratoga } \\
\text { Investama Sedaya }\end{array}$ & $-5,40$ & 0,68 & 6,09 & $-0,40$ & 1,15 & $-1,55$ \\
\hline 9. & PT Bakrie Brother & 4,91 & $-12,17$ & $-17,08$ & 1,24 & 7,79 & $-6,54$ \\
\hline 10. & $\begin{array}{l}\text { Chevron } \\
\text { Corporation; }\end{array}$ & 6,15 & 1,06 & $-5,09$ & 1,32 & 0,68 & 0,64 \\
\hline 11. & $\begin{array}{l}\text { Aboitiz Power } \\
\text { Corporation; }\end{array}$ & 14,60 & 0,77 & $-13,83$ & 3,01 & 1,16 & 1,85 \\
\hline 12. & Ayala Corporation; & 32,95 & 2,14 & $-30,81$ & 3,21 & 0,88 & 2,33 \\
\hline 13. & $\begin{array}{l}\text { Energy } \\
\text { Development Corp. }\end{array}$ & 1,65 & 0,34 & $-1,31$ & 1,23 & 1,02 & 0,21 \\
\hline 14. & $\begin{array}{l}\text { First Gen } \\
\text { Corporation; }\end{array}$ & 5,23 & 0,34 & $-4,89$ & 1,51 & 0,80 & 0,70 \\
\hline 15. & $\begin{array}{l}\text { San Miguel } \\
\text { Corporation; }\end{array}$ & $-0,76$ & 0,51 & 1,26 & 0,16 & 0,82 & $-0,66$ \\
\hline 16. & $\begin{array}{l}\text { Philipines National } \\
\text { Oil Company; }\end{array}$ & 0,49 & 0,17 & $-0,32$ & 0,42 & 1,06 & $-0,64$ \\
\hline
\end{tabular}

Sumber: Diolah oleh peneliti

Dari Tabel 2, telah diketahui kondisi keuangan dan tingkat value creation perusahaan. Sebagai contoh, diuraikan penjelasan pada perusahaan yang berada mewakili pada posisi:

\section{Kuadran I;}

Sebagai representasi dari kuadran I diwakilkan oleh perusahaan Ayala Corporation. Pada perusahaan Ayala Corporation, hasil penelitian menunjukkan bahwa kombinasi nilai SGR sebesar 2,14 \% dan Growth in sales sebesar 32,95 \%, kondisi perusahaan cash deficit sebesar -30,81\%. Ini mengindikasikan bahwa perusahaan Ayala Corporation dapat meraih profit secara berkelanjutan dalam waktu 5 tahun ini, dan juga mampu menghasilkan tingkat pertumbuhan penjualan. Sayangnya perusahaan akhirnya menuju pada kondisi potensi laju cash deficit juga, akibat dari aktifitas tingkat pertumbuhan Growth in sales masih terlalu tinggi, yang terlalu cepat sehingga biaya untuk sales membengkak tak terkendali, sehingga menggerus porsi dana cash dari hasil tingkat pertumbuhan SGR. 
Sedangkan nilai ROIC sebesar 0,88\% dan nilai WACC sebesar 3,21\% serta spread EVA sebesar 2,33 \%. Hal ini dapat diasumsikan bahwa perusahaan sudah bisa membuat efisiensi penggunaan dana dari anggaran operasionalnya, dan juga berhasil mendapatkan pertumbuhan value creation. Untuk itulah secara keseluruhan corporate growth mengalami cash deficit akibat aktual (growth in sales) melebihi pertumbuhan yang seharusnya (SGR). Sehingga Ayala Corporation di kriteria posisi kuadran I

Dengan kondisi value creation spread EVA > nol, bearti perusahaan Ayala Corporation mengalami kondisi keberhasilan dalam menggapai nilai tambah untuk perusahaannya. Menurut Wijaya dan Tjun (2009:182), Economic Value Added dijadikan pula indikator internal yang mengukur kekayaan pemegang saham suatu perusahaan dalam jangka waktu tertentu. EVA mengukur seberapa efisien perusahaan mengunakan modalnya untuk menciptakan nilai tambah ekonomis. Penelitian Erasmus (2006:3) menyatakan EVA dapat digunakan sebagai alat untuk mengukur seberapa besar tingkat nilai tambah atau value creation yang dihasilkan oleh suatu perusahaan. Nilai EVA > nol, diasumsikan bahwa telah terciptanya nilai tambah pada perusahaan tersebut, disebabkan nilai profit yang dapat di peroleh bisa memenuhi keinginan para pemegang saham.

Ross et al. (2012:109) menyatakan bahwa Growth in sales merupakan tingkat pertumbuhan maksimum yang dapat dicapai oleh corporate tanpa membutuhkan external fund, (SGR < Growth in sales), Penelitian Joni dan Hendrawan (2013:6), bahwa Growth in sales dapat dibandingkan dengan nilai SGR untuk mengetahui tingkat financial cash. Jika perbandingan berupa nilai negatif (SGR < Growth in sales), hal ini mengindikasikan bahwa ada cumulative cash deficit yang terjadi pada perusahaan selama beberapa tahun terakhir ini. Sehingga perusahaan masuk dalam kondisi cash deficit.

\section{Kuadran III;}

Untuk representasi dari kuadran I diwakilkan oleh perusahaan PT Pertamina (Persero). Hasil analisa pada PT Pertamina (Persero) menunjukan bahwa kombinasi nilai SGR yang di peroleh adalah sebesar $0,88 \%$ dan Growth in sales yang di dapat sebesar adalah $-0,26 \%$, dengan kondisi keuangannya cash surplus sebesar 1,14\%. Ini 
mengindikasian bahwa perusahaan PT Pertamina (Persero) masih tetap mampu bertahan menjaga dan menghasilkan keuntungan secara berkelanjutan. Namun PT Pertamina (Persero) ternyata belum mampu lagi menambah atau meningkatkan pertumbuhan sales sesuai harapan perusahaan. Sedangkan nilai ROIC sebesar $0,80 \%$ dan nilai WACC sebesar $1,16 \%$, serta nilai spread EVA sebesar $-0,35 \%$.

Hal ini diartikan bahwa perusahaan PT Pertamina (Persero) tidak mampu menciptakan tingkat pertumbuhan value creation yang baik sebagaimana mestinya walaupun dalam kondisi aset dana yang masih cash surplus, dikarenakan dana cash tersebut telah digunakan mendukung segala aktifias sales, yang telah menyerap alokasi dana secara besar untuk pelaksanaan alokasi biaya-biaya operasional yan muncul, sehingga menyebabkan perusahaan berada dalam kondisi value destruction. Bila perusahaan dimasukkan pada kriteria kuadran matriks ini maka PT Pertamina (Persero) berada pada bagian posisi kuadran III.

Dengan kondisi nilai $G$ in sales dan tingkat value creation spread EVA < nol, bearti perusahaan PT Pertamina (Persero) belum berhasil menciptakan nilai tambah ke dalam perusahaan, sehingga dapat mengalami value detruction, dan dalam kondisi perusahaan kurang sehat, kekuatan keuangan perusahaan belum stabil, serta tertimpah masalah keuangan perusahaan yang merugi. Menurut Brigham and Houston (2006:39) menyatakan terkait nilai EVA < nol, artinya tidak ada nilai tambah ke dalam perusahaan, disebabkan profit yang ada tidak bisa memenuhi keinginan para pemegang saham (shareholders), padahal penciptaan EVA merupakan kemakmuran yang bisa dibuat untuk pemegang saham melalui kenaikan harga saham dan dividend yang dibayarkan.

Hawawini and Viallete (2011:550), telah menyatakan jika SGR > G in sales, bahwa adanya peningkatan cash surpluses. Rasio nilai rata-rata growth ditentukan mengacuh pada perbedaan besaran rasio SGR dan nilai actual growth in sales. Jika perbandingan menghasilkan rasio nilai SGR > Growth in sales, maka dapat di ambil kesimpulan bahwa pada perusahaan tersebut terjadi peningkatan yang positif dari dana cumulative cash surplus. 

http://doi.org/10.21009/JRMSI

Hawawini and Viallete (2011:538), mengemukakan bahwa strategi penciptaan nilai dengan mencapai pertumbuhan keuntungan (profitable sales growth). Namun bila perusahaan dalam kondisi cash deficit, di mana perbedaan tingkat pertumbuhan yang tinggi ( $G$ in sales $>S G R$ ) maka dapat dimaknai bahwa nantinya bisa saja terjadi suatu potensi financial distress pada perusahaan tersebut bilamana perusahaan tersebut tidak segera dikendalikan atau mengantisipasi masalah keuangan yang dapat tiba-tiba muncul.

\section{Kuadran IV;}

Selanjutnya untuk representasi dari kuadran I diwakilkan oleh PT Medco Energi Internasional Tbk. Pada analisa PT Medco Energi Internasional Tbk dalam penelitian ini menunjukan bahwa kombinasi nilai SGR sebesar 2,07\% dan Growth in sales sebesar $3,44 \%$, dengan kondisi keuangannya berada pada cash deficit yang mencapai sebesar 1,36 \%. Kondisi ini mengindikasikan bahwa pada perusahaan PT Medco Energi Internasional Tbk telah berhasil meraih benefit dan juga berhasil meningkatkan pertumbuhan $G$ in sales. Namun PT Medco Energi Internasional Tbk masih akan menghadapi masalah keuangan (cash deficit) yang disebabkan oleh laju pertumbuhan $G$ in sales yang lebih besar dari pada tingkat pertumbuhan SGR, di mana dana benefit tersedot abis ke alokasi biaya-biaya operasional dan biaya-biaya aktifitas perusahaan lainnya. Sedangkan pencapaian total return ROIC adalah sebesar 0,81\% dan nilai WACC sebesar 6,06\% serta spread EVA sebesar -5,25\%.

Hal ini mempresentasikan bahwa perusahaan PT Medco Energi Internasional Tbk dalam periode tahun penelitian ini tidak bisa mencapai peningkatan value creation, di ikuti oleh masalah kondisi menuju cash deficit, dan juga berpotensi akan mengalami masalah keuangan yang cukup serius (financial distess). Kondisi ini dikarenakan laju growth secara aktual Growth in sales lebih besar dari pada capaian laju growth SGR yang seharusnya, konsekwensinya perusahaan berada dalam kondisi value destruction. Sehingga perusahaan PT Medco Energi Internasional Tbk beberapa tahun ini perusahaannya berada dalam kondisi pada bagian posisi kuadran IV di dalam matriks kuadran.

Tandelilin (2001:195), beranggapan EVA adalah ukuran keberhasilan manajemen perusahaan dalam meningkatkan nilai tambah (value added) bagi perusahaan. 
Sedangkan pada sales growth, menurut Barton et al. (1989:304) adalah sebagai pertumbuhan penjualan yang mencerminkan manifestasi keberhasilan investasi di periode masa lalu, dan dapat dijadikan sebagai prediksi pertumbuhan masa mendatang. Disituasi seperti ini, mencerminkan bahwa dapat terjadinya cash deficit pula di masa mendatang pada perusahaan, bila tidak cermat dan segera dalam mengendalikannya. Sehingga perusahaan perlu segera mengambil langkah-kangkah kebijakan keuangan agar dapat menyelamatkan dana cash yang ada.

2. Posisi perusahaan dari kondisi pertumbuhan perusahaan dan tingkat value creation di dalam 4 bagian kuadran matriks

Hawawini and Viallete (1998:507) mengemukakan bahwa strategi keuangan matriks dapat bermanfaat juga untuk mengetahui kondisi keuangan dan value creation yang di lihat dari nilai tambah ekonomi terkait penciptaan nilai pada suatu kelompok perusahaan. Penilaian dapat di lihat dari kondisi value creation dari nilai EVA (EVA $>0$ ataupun EVA <0), dan juga kondisi keuangan (cash surplus ataupun cash deficit) di setiap perusahaan. Hasil dari analisanya dapat di lihat gambar 4.1:

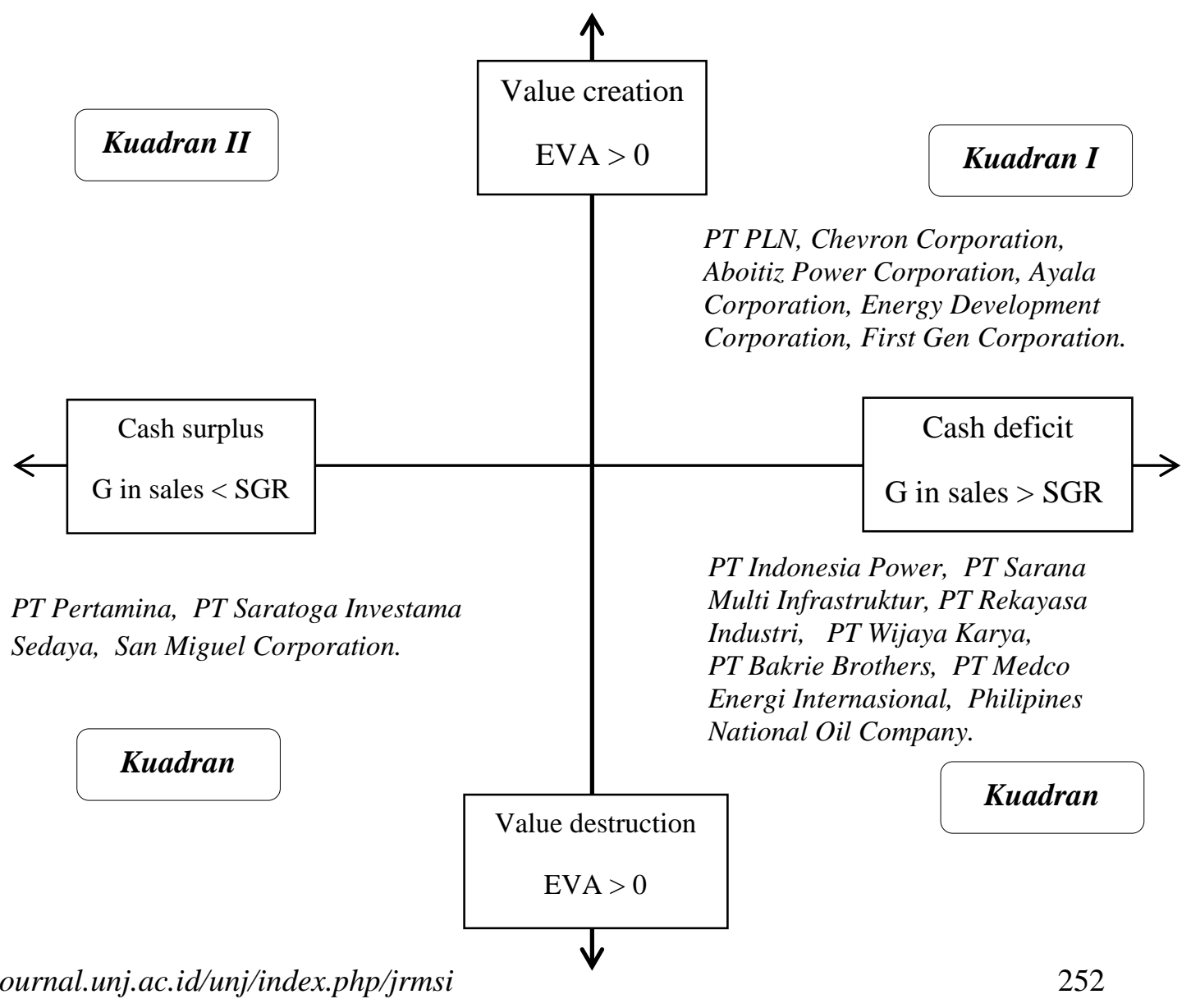


Sumber: Diolah oleh peneliti

\section{Gambar 2. Posisi perusahaan dari kondisi rata-rara pertumbuhan dan tingkat value creation}

Dapat kita ketahui dari peta kuadran matriks pada Gambar 2. bahwa adanya kelompok-kelompok perusahaan yang masuk dalam masing-masing kuadrannya, kelompok kuadran perusahaan dijelaskan sebagai berikut: Kelompok Kuadran I, dalam hal ini terdiri dari perusahaan PT PLN, Chevron Corporation, Aboitiz Power Corporation, Ayala Corporation, Energy Development Corporation, dan First Gen Corporation.

Dari beberapa perusahaan yang masuk dalam kelompok tersebut, direpsentasikan maka dapat diberikan uraian analisa, misalnya untuk Kuadran I dalam hal ini dapat direpsentasikan oleh perusahaan PT PLN (Persero). Analisis pertumbuhan digunakan untuk mengetahui presentase perubahan aset, kewajiban dan ekuitas yang dimiliki PT PLN (Persero). Nilai perputaran aktiva tetap yang tidak besar menunjukkan bahwa PT PLN (Persero) kurang efektif dalam menggunakan aset tetapnya untuk menghasilkan pendapatan. Pada situasi financial condition yang mengalami cash deficit, namun telah tercipta kondisi pertumbuhan value creation, maka konsekwensi yang mungkin dapat terjadi diantaranya bahwa PT PLN (Persero) akan termasuk dalam kelompok perusahaan cukup stabil tingkat keuangannya, walau perusahaan harus masih terus meningkatkan efisiensinya. Namun perusahaan PT PLN (Persero) harus mewaspadai ancaman masalah keuangan (financial distress) di periode mendatang. Perusahaan juga saat ini belum layak membagikan dividend kepada shareholders. Menurut Sari (2005) mengkategorikan perusahaan dengan financial distress apabila selama dua tahun berturut-turut mengalami laba operasi negatif. Menurut Azwar (2015:9) manfaat menganalisa masalah tekanan keuangan antara lain dapat mengambil keputusan atau tindakan memperbaiki segera keadaan ataupun untuk menghindari permasalahan keuangan.

PT PLN (Persero) akan mampu memenuhi kewajiban-kewajibannya (kewajiban jangka pendek maupun jangka panjang) jika menggunakan keseluruhan aset tidak lancarnya, disamping aset lancarnya. Padahal seperti diketahui, aset tetap bersifat 
kurang likuid di banding aset lancar. Perusahaan PT PLN (Persero) patut mengembangkan strategi pertumbuhan cabang pembangkit baru di daerah namun tetap mengendalikan tingkat efisiensi yang optimal dan penjualan energi, membuat diversifikasi jasa baru bagi pelanggan listrik, dan menangguhkan pembiayaanpembiayaan baru di unit bisnisnya sektor hulu. Hal lain yang dapat dilakukan seperti perusahaan harus melakukan retained earning, mengupayakan raising fund, dan mengurangi pertumbuhan $G$ in sales sampai selaras dengan tinggal tingkat SGR. Laju pertumbuhan berkelanjutan adalah tingkat pertumbuhan pendapatan maksimum yang memungkinkan perusahaan memanfaatkan dana hasil usaha internal (dana organik), untuk tingkat pengembalian ekuitas yang diketahui tanpa mengubah struktur permodalan, yaitu strategi operasional dan keuangan, sambil mempertahankan sumber daya keuangan (Higgins,1989; Virani, 2013). Penelitian Geiger and Reyes (1997) menggunakan model SGR untuk membantu pemilik usaha enterprise untuk menentukan tingkat pertumbuhan yang sesuai untuk tingkat biaya dan hutang perusahaan.

Kelompok Kuadran III, yaitu terdiri dari perusahaan PT Pertamina, PT Saratoga Investama Sedaya, dan San Miguel Corporation.

Untuk representasi dari kelompok Kuadran III, dalam hal ini bisa direpresentasikan oleh perusahaan San Miguel Corporation. Saat financial condition perusahaan San Miguel Corporation mengalami cash surplus dan namun disayangkan situasi keadaan pertumbuhan nilai perusahaan tersandung hambatan value destruction. Oleh sebab itu menurut teori Hawawini and Viallete (2011) maka konsekwensi logisnya bahwa San Miguel Corporation akan masih termasuk kelompok cluster perusahaan yang dapat bertahan untuk survival mempertahankan perusahaan untuk tetap dalam kondisi yang agak lebih baik kembali, dengan mempertahankan kemampuan menghasilkan growth value, SGR, dan berupaya mempertahankan shares value, dan total return secara berkelanjutan.

Perusahaan juga perlu berorientasi meningkatnya cash revenue pada tahun-tahun mendatang demi terciptanya target value creation bagi perusahaan. Perusahaan San Miguel Corporation harus fokus pada peningkatan efisiensi perusahaan, mereduksi perkembangan yang berimbas pada $G$ in sales yang tinggi. Selain itu perusahaan harus 
tidak perlu mengeluarkan dividend pada beberapa tahun ke depan, dan berupaya segera meningkatkan nilai return margin, juga menurunkan beban biaya cost of capital yang rasio WACC yang besar, serta menahan kegiatan investasi baru.

Kelompok Kuadran IV, ialah terdiri dari perusahaan PT Indonesia Power, PT Sarana Multi Infrastruktur, PT Rekayasa Industri, PT Wijaya Karya, PT Bakrie Brothers, PT Medco Energi Internasional, dan Philipines National Oil Company.

Untuk uraian analisa kelompok Kuadran IV, dalam hal ini boleh direpresentasikan dari perusahaan PT Bakrie Brothers Tbk. Saat ini perusahaan PT Bakrie Brothers Tbk menurunkan biaya-biaya, aset-aset yang tidak efisien, mesin tua, restrukturisasi, termasuk pergantian sumber daya manusia yang lebih berusia muda. Secara fundamental perusahaan di anggap sudah lebih baik ketimbang tahun-tahun lalu. Apalagi perseroan terus berupaya mengurangi beban hutang lewat sejumlah opsi ke kreditur lewat konversi saham. Perusahaan PT Bakrie Brother Tbk, di dalam situasi beban biaya Growth in sales yang terus membengkak, yang mana perusahaan mengalami financial condition yang tidak cukup sehat, yang terus merambah pada kondisi cash deficit dalam jangka waktu 5 tahun ini. Perusahaan menghadapi hambatan pertumbuhan yang tidak diinginkan yaitu dalam pertumbuhan nilai pada tingkat value destruction, maka dengan begitu konsekwensi logis yang akan dialami oleh perusahaan PT Bakrie Brothers Tbk antara lain dalam periode ini perusahaan dalam kondisi yang lemah, keadaan kekuatan keuangannya pun sangat tidak stabil, serta masih menghadapi tantangan masalah tekanan financial distress selama 5 tahun terakhir.

Berkenaan dengan memprediksi kelangsungan hidup suatu perusahaan, maka perusahaan perlu konsen memperhatikannya, dikarenakan hal ini di anggap sangat penting bagi manajemen dan pemilik perusahaan, agar dapat membuat strategi pertumbuhan berkelanjutan (sustainable growth rate). Juga berguna untuk mengantisipasi kemungkinan potensi financial distress, dan bila berlanjut terus maka dapat memberi tanda awal keberadaan financial distress dan bankrupt (Brahmana, 2005:3). Penelitian Whitaker (1999) menyatakan bahwa financial distress dapat dilihat ketika perusahaan dalam beberapa tahun mengalami laba operasi yang negatif. 
Kondisi perusahaan tidak memiliki dividend yang cukup untuk shareholders. Perusahaan harus melakukan evaluasi secara komprehensif terkait kinerja organisasi perusahaan guna memperbaiki situasi corporate value agar mengapai pertumbuhan yang sesuai dan selalu positif serta berupaya keluar dari financial distress. Perusahaan diharapkan pula dapat memperbaiki kinerja perusahaan dan melakukan peningkatan efisiensi, berupaya segera meningkatkan total return, mengendalikan biaya cost of capital ke arah yang lebih rendah. Penelitian Ariawan (2016:2) telah menyampaikan bahwa financial distress merupakan suatu kondisi di mana perusahaan mengalami kesulitan keuangan untuk memenuhi kewajiban-kewajibannya. Indikasi terjadinya kesulitan keuangan atau financial distress dapat diketahui dari kinerja keuangan suatu perusahaan.

Strategi keuangani keuangan yang dapat dilakukan oleh perusahaan setelah mengetahui kondisi value creation pada kuadran matriksnya, pada grafik kuadran di Gambar 2, terlihat tidak ada corporate yang berada di kuadran II (hanya berada di kuadran I, III, dan IV). Perusahaan yang berada di posisi kuadran I diartikan bahwa kelompok corporate tersebut sudah membuat value creation tetapi pertumbuhan nilai growth in sales perusahaan terlalu cepat sehingga menuju pada kondisi potensi cash deficits. Growth mengalami kekurangan dana akibat aktual (growth in sales) melebihi pertumbuhan yang seharusnya (SGR). Perusahaan-perusahaan yang berada pada kuadran I ini adalah PT PLN (Persero), Chevron Corporation, Aboitiz Power Corporation, Ayala Corporation, Energy Development Corporation, dan First Gen Corporation. Dengan kondisi financial seperti itu, corporate direkomendasikan untuk membuat keputusan dan melaksanakan strategi keuangan diantaranya: 1) Menahan dividen (cut dividend) dan membuat kebijakan retained earning. 2) Menggalang dana melalui shares (penerbitan saham atau surat utang). 3) Meredam laju pertumbuhan aktual sampai stabil dengan pertumbuhan SGR, dengan cara mereduksi profit marjin dan juga perputaran aktiva bersih.

Bagi perusahaan di posisi kuadran III, mengalami pertumbuhan aktual lebih kecil dari pada pertumbuhan seharusnya (nilai growth in sales lebih kecil dari pada nilai SGR), sehingga mengalami value destruction (EVA lebih kecil dari nol). Pada kuadran III ini dapat dikatakan bahwa perusahaan masih dalam kondisi aset dana cash surplus 
walau nilai EVA negatif. Perusahaan yang berada dalan kuadran III yaitu PT Pertamina, PT Saratoga Investama Sedaya Tbk, dan San Miguel Corporation.

Dengan kondisi financial seperti ini, corporate direkomendasikan untuk melakukan pilihan strategi keuangan dari beberapa hal, diantaranya: 1) Menggunakan kelebihan dananya untuk kegiatan memperbesar profit atau investasi dengan cara meningkatkan efisiensi dan efektivitas penggunaan aktiva bersih dan meningkatkan profit marjin baik melalui penambahan kapasitas produksi, menambah transaksi kontrak jual energi maupun melalui program sarana efisiensi pengendalian pengeluaran biaya-biaya operasional. 2) Mengevaluasi struktur permodalan atau review keputusan pembiayaan corporate dengan mengkombinasikan rasio debt dan equity sampai pada tingkat yang menciptakan biaya penggunaan dana terkecil atau menjaga debt to equity ratio yang lebih kecil dari pada beban WACC. 3) Alternatif kebijakan lain ialah corporate harus mengandalkan dana grant atau venture dari lembaga internasional dan bantuan pemerintah, ataupun sepenuhnya mengharap mitra investor untuk kegiatan pembiayaan dan investasi proyek baru. 4) Bila pilihan strategi di atas tidak berhasil dilaksanakan maka corporate dalam kondisi yang buruk, dapat di buat pilihan untuk menjual bisnis tersebut.

Sedangkan pada kondisi kuadran lainnya, yaitu kelompok corporate yang sebagian besar pertumbuhan corporate berada dalam kuadran IV, yaitu matriks kuadran yang mengilustrasikan kondisi pertumbuhan nilai aktual corporate lebih besar dari pada pertumbuhan seharusnya (nilai growth in sales lebih besar dari pada nilai SGR), namun sayangnya juga menghasilkan destruction (EVA lebih kecil dari nol). Pada kuadran IV ini mengindikasikan corporate dalam keadaan aset dana cash defisit dan EVA negatif. Kuadran IV mengartikan bahwa corporate selain tidak menciptakan nilai tambah (destroys value), juga mengarah pada cash deficits karena corporate growth secara aktual lebih besar dari growth yang seharusnya (SGR). Kuadran IV ini merupakan kuadran yang dalam situasi terburuk, dan memerlukan perhatian dan tindakan manajemen sesegera mungkin (fast action by management). Kelompok perusahaan yang berada pada kondisi kuadran IV adalah PT Pertamina (Persero), PT Indonesia Power (Persero), PT Sarana Multi Infrastruktur (Persero), PT Rekayasa Industri (Persero), PT Wijaya Karya (Persero), PT Bakrie Brothers Tbk, PT Medco Power Energi Internasional Tbk, dan Philipines National Oil Company. Dalam keadaan 
seperti ini, direkomendasikan merestrukturisasi secara drastis, beberapa aset bisnis bisa di jual agar segera meningkatkan dana (cash), selanjutnya mengurangi aktifitas operasioperasi lain untuk merubahnya menjadi aktifitas-aktifitas value creating agar bertahan pada bisnisnya. Dalam posisi yang kurang menguntungkan ini, direkomendasi pula kebijakan untuk memperbaiki financaial ratio condition pada corporate yaitu dengan cara corporate harus bisa menunda beberapa kegiatan proyek pembiayaan dan investasi proyek baru. Sedangkan proyek yang telah ada dapat ditawarkan kembali untuk menarik modal dana lain, joint venture dengan investor atau pemodal besar baru yang bergerak di bidang yang sama, serta mengajukan dan memanfaatkan sumber-sumber dana lain dari pihak eksternal seperti lembaga Climate Investment Fund (Irfina,2014).

II

- Gunakan surplus kas agar tingkat pertumbuhan perusahaan lebih baik lagi:

- melakukan investasi baru (pertumbuhan organik).

- akuisisi pada bisnis yang masih terkait.

- Membagikan surplus kas:

- meningkatkan pembayaran dividen.

- pembelian kembali saham.

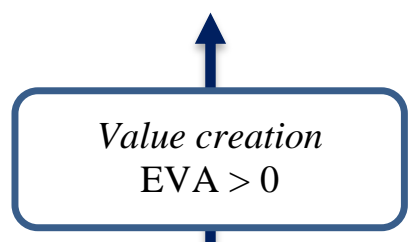

I

- Menahan atau memotong nilai dividen.

- Meningkatkan cadangan dana:

- menggalang sumber ekuitas baru.

- meningkat pinjaman

- Kurangi pertumbuhan Growth in sales hingga ke tingkat yang berimbangan dengan level SGR.

- keluar dari unit usaha yang menghasilkan margin rendah dan kegiatan usaha yang modalnya rendah.

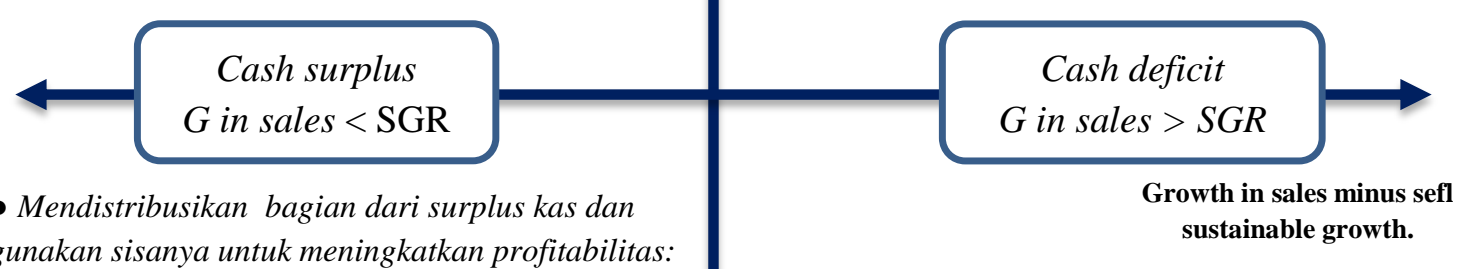

- menciptakan efisiensi di mana aset dikelola.

- meningkatkan marjin operasi (volume lebih tinggi, harga lebih tinggi, dan pengendalian biaya yang lebih tinggi).

- Mninjau kembali kebijakan struktur modal: - jika struktur modal saat ini tidak optimal, maka ubah rasio hutang terhadap ekuitas agar menurunkan biaya rata-rata modal tertimbang.

- Jika cara di atas masih tidak berhasil, maka di jual saja proyek bisnisnya.

\section{III}

- Segera melakukan restrukturisasi secara drastis atau cukup keluar dari bisnis tersebut.
Value destruction

EVA $<0$ 
Sumber: Diolah oleh peneliti dari Hawawini and Viallete model, 2011:551.

\section{Gambar 3. Matrik strategi keuangan}

\section{KESIMPULAN DAN SARAN}

\section{Kesimpulan}

Dari hasil penelitian dan analisa yang telah dilakukan dapat disimpulkan dengan strategi keuangan matriks (model Hawawini-Viallete), maka dapat mengetahui kondisi keuangan perusahaan dan tingkat value creation. Juga dapat ditentukan posisi perusahaan dari kondisi pertumbuhan perusahaan dan tingkat value creation di dalam 4 bagian kuadran matriks. Selain itu mampu merekomendasikan strategi keuangan yang dapat dilakukan oleh perusahaan. Pada kondisi keuangan tahun penelitian, hampir semua perusahaan di bidang energi geothermal yang berada di kawasan ASEAN sedang dalam kondisi cash deficit. Sehingga perusahaan-perusahaan tersebut perlu melakukan upaya efisiensi untuk peningkatan dana dari sumber internal maupun eksternal dan retained earning. Pada peta posisi tingkat rata-rata pertumbuhan keuangan perusahaan, telah dapat diketahui bahwa perusahaan yang memiliki pertumbuhan relatif pada tingkat SGR dapat secara signifikan berdampak mempengaruhi cash position. Pertumbuhan tingkat Sales growth yang lebih cepat dari pada SGR pada umumnya dapat menyebabkan Cash deficit. Sedangkan tingkat Sales growth yang lambat dari SGR dapat menyebabkan mengembangnya Cash surpluses. Pada tahun penelitian tidak ada perusahaan yang berada pada kuadran II. Dengan menggunakan strategi keuangan matriks, dapat direkomendasikan strategi keuangan bagi masing-masing perusahaan, dan diharapkan posisi keuangan perusahaan untuk selalu dapat berada pada kuadran II dan I.

\section{Saran}

Sebagai saran bagi pihak investor, sebaiknya lebih melihat value creation dan kondisi keuangan yang lebih fokus pada pertumbuhan berkelanjutan (sustainable growth) dengan keseimbangan antara pertumbuhan aktual dan pertumbuhan yang seharusnya (balance of internal and external growth). Bagi perusahaan yang sedang mengalami cash deficit, dapat mencoba untuk menggalang dana sumber internal dan 
eksternal perusahaan. Untuk penelitian selanjutnya sebaiknya memfokuskan satu sampel perusahaan namun menambah varabel dan memperpanjang periode waktu, sehingga diharapkan dapat memberikan hasil analisis yang lebih rinci.

\section{DAFTAR PUSTAKA}

Alam, P., \& Nizamuddin, M. (2013). Performance measures of shareholders wealth: an application of Economic Value Added (EVA). International journal of applied financial management perspectives, Pezzottaite Journals, 2 (2), 160-166.

De Wet, J.H.V.H, \& Hall,J.H. (2004). The relationship between EVA, MVA and leverage. Meditari Accountancy Research, 12 (1), 39-59.

Devie. (2003). Strategi keuangan matriks: Alat bantu keputusan investasi dan pembiayaan. Jurnal akuntansi dan keuangan Universitas Kristen Petra, 5, 58-74.

Hall, J.H. (2013). Toward improved use of value creation measures in financial decision-making. The Journal of Applied Business Research, 29 (4),1175-1178.

Ibrahim, Riki. (2011). Pembuatan anggaran dan penyampaian laporan kegiatan proyek geothermal. PII course, 1-70.

Ibrahim, R., Rumata, U.S., \& Jarman. (2014). Indonesia geothermal development for power project, Indonesian Electrical Power Society, 1-32.

Irfina, Dina (2014). Business Model for Geothermal Experience in Indonesia, (Jakarta: Center for Climate Change Financing and Multilateral Policy, Fiscal Policy Agency, Ministry of Finance, Republic of Indonesia).

Joni, dan Hendawan, Bambang. (2005). Kinerja keuangan perusahaan go-publik di kawasan perdagangan bebas dan pelabuhan bebas Batam, Jurnal Manajemen Bisnis, Politeknik Negeri Batam, 1, 1-5.

Meythi. (2013). Rasio Keuangan Terbaik Untuk Memprediksi Nilai Perusahaan, Jurnal Keuangan dan Perbankan Universitas Kristen Maranatha, 17 (2), 200-210.

Purnamasari, R., Suci, R.P, dan Handini, D.P. (2013). Strategi keuangan matriks sebagai Alat bantu keputusan investasi dan pembiayaan. Jurnal Manajemen dan Akuntansi Universitas Widyagama Malang, 2 (2), 95-107.

Rahmat, Pupu Saeful. (2009). Penelitian Kualitatif, Jurnal Equilibrium, 5 (9), 1-8.

Ridwan, Kiagus. (2014). Geothermal capital overview, (Jakarta: Mineral And Industrial Institute).

Ross, A.R, Westerfield, R.W, Jordan, B.D, Tan, R. (2010). Fundamentals of corporate finance, New York : MacGraw Hill.

Shil, N.C. (2009). Performance Measures: An application of economic Value Added, International Journal of Business and Management, 4 (3), 169-177. 
Wahyudi, Yunus. (2013). Strategi keuangan matriks dan Optimalisasi struktur modal untuk pertumbuhan perusahaan berkelanjutan: Studi pada PT Adhimix Precast Indonesia, (Yogyakarta: FEB-UGM).

Wintolo, D., Toha, B., dan Hendrayana, H. (1994). Kemungkinan pendekatan statistik terhadap ketidakpastian pada pemodelan investasi eksplorasi panasbumi, Jakarta. Lokakarya Energi 94, 1-9.

Yuniawati, R.D. (2012). Analisis strategi keuangan matriks Bank Perkreditan Rakyat $(B P R)$, (Yogyakarta: FEB-UGM). 